\title{
Effects of Country of Origin in Product Categories: A Study Concerning Italy and Great Britain
}

\author{
Elisa Rancati, PhD, MA \\ University of Milan-Bicocca, Italy \\ Alessandro D'Agata, Marketing Coordinator \\ Playmarketingch, Switzerland
}

\begin{abstract}
This study examines country-of-origin in terms of the fit between two countries (Italy and Great Britain) and product categories. A framework is suggested which matches the importance of product category dimensions with the perceived image of the country-of-origin along the same dimensions. Such matches (or mismatches) can influence or not the customers in their decisionmaking process in a different manner concerning the country. Data collected from consumers in Italy and Great Britain demonstrate that strategic implications can increase sales in some category. This study has underlined the presence of an important domestic bias concerning convenience goods category, especially in food purchases. Instead, in specialty goods category, the customer seems to identify and prefer specific countries, and goods are critically evaluated for their origin.
\end{abstract}

Keywords: Country Of Origin, Country Of Image, Products

\section{Introduction}

The country-of-origin effect is a strategic variable in selling, influencing the purchase of a product and changing customers' perception about quality, expectations, and satisfaction. This effect is particularly studied by researchers because of the many different opinions concerning the consequences on products and sales (Seeman, Gould, Chao and Grein, 2019; Yoon and Lee, 2019). In the era of globalisation, customers know everything about a product before buying it and choose can be distorted by the media, brands and personal culture. Globalisation has increased the effects of the country-of-origin concept (Karimov and El-Murad, 2019): consumers can normally find a product from any country any day in shops and supermarkets around the world. The country-of-origin effects can be different in product categories. Many studies have underlined how strong or weak the effects are 
depending on the category (Andehn, Nordin and Nilsson, 2015) to which the product belongs. It can be important for business purposes to know how much it can gain or lose in terms of profits only due to the product's origin. Impact that products from less developed countries and products from developed countries have on sales in markets could be different, not only by product categories, but also because of the country-of-origin image. Such variables represent in the mind of customers a set of relevant attributes according to which a product automatically gains from its country of origin (Costa, Carniero and Goldszmidt, 2016).

\section{Literature review:}

\section{The country-of-origin image}

The country-of-origin image $(\mathrm{COI})$ is the total of features that consumers identify with a specific country and that can influence their consumption behaviour and perception, brand association, perceived quality and brand loyalty (Listiana, 2015). The country-of-origin image of a country is the result of a lot of elements and variables such as historical events and facts, political events, cultural revolutions, ethnic group and demographic evolution, traditions, famous companies and products, specific industry skills (Bassi Suter, Mendes Borini, Eliete Floriani, Da Silva and Polo, 2018).

\section{The country-of-origin effects}

The country-of-origin effects (COE) is the set of components that influences customers in their purchases and the companies producing location choices regarding the origin of the goods. The origin of products is strictly correlated with the choice of the company's location. As it is well known, this choice can influence many business variables such as transportation, supply of raw materials, economic policy, government's decisions, subsidies, fees and firm innovation capacity (Ferreira, Fernandes and Raposo, 2017). A negative COI can account for these negative effects.

\section{The influence of the country-of-origin effects in product categories}

Many studies about the country-of-origin have their focus on the effects that influence the customers' perceived quality, while a few try to match these effects with different product categories (Sjostrom, Corsi and Lockshin, 2016). It has been demonstrated that the effects are different if we change the product category of interest. This study analyses three categories of products, i.e. convenience products, shopping products, specialty products. Consumers represent by the products that are bought more easily, frequently and without efforts convenience goods. The decision-making process for these products is normally very short, and this could be a problem for studies in this category (Rasha, 2015) in cross-national analysis. This research analysed six 
goals related to the convenience product category in Great Britain and in Italy: H1: the influence of $\mathrm{COE}$, on a potential decision-making process related to a convenience good in Italy, is significantly relevant; H2: Is the influence of COE - on an already bought convenience good in Italy - significantly relevant; H7: the influence of $\mathrm{COE}$, on a potential decision-making process related to a convenience good in Great Britain, is significantly relevant; H8: the influence of $\mathrm{COE}$, on an already bought convenience good in Great Britain, is significantly relevant. The consumers choose shopping goods after a process of comparison concerning their attributes and the decision-making process is longer than in the previous category. The range of variables inherent the goods are wide: brand, previous purchased, packaging (Momani, 2015). The goals of the research in the shopping goods category in Great Britain and Italy are: H3: the influence of the $\mathrm{COE}$, on a potential decision-making process related to a shopping good in Italy, is significantly relevant; H4: the influence of the COE, on an already bought shopping good in Italy, is significantly relevant; H9: Is the influence of the $\mathrm{COE}$, on a potential decision-making process related to a shopping good in Great Britain, is significantly relevant; H10: the influence of the COE, on an already bought shopping good in Great Britain, is significantly relevant. Specialty goods are related to the country-of-origin: the origin of the goods is usually a characteristic that is specifically requested by the consumer and it is a sort of quality guarantee (Rafi and Rafi, 2015). This research will try to understand the following problems concerning this category in Great Britain and in Italy: H5: the influence of the COE, on a potential decision-making process related to a specialty good in Italy, is significantly relevant; H6: the influence of the COE, on an already bought specialty good in Italy, is significantly relevant; H11: the influence of the $\mathrm{COE}$, on a potential decision-making process related to a specialty good in Great Britain, is significantly relevant; H12: the influence of the COE, on an already bought specialty good in Great Britain, is significantly relevant.

\section{Methodology}

The empirical materials were gathered in Milan and Glasgow in June and July 2019: the research population in each country has been sampled from teenagers between 18 and 26 years old. Researchers have decided to collect data teenager population because they should have a greater knowledge concerning products of origin. Their young age could allow researchers to understand future trends of the $\mathrm{COO}$ effects. In total, researchers gathered 119 questionnaire responses: in Great Britain, researchers have collected 64 questionnaires while in Italy they have collected 54 questionnaires. The two questionnaires have been in two different languages, the translation of the questions has been accurate to avoid shifts in meaning. This process has been very important since a different meaning of a question could have spoilt the 
comparison of the results. The questionnaires were designed to capture statistical trends on the consumer awareness of the country-of-origin of the goods and the country-of-origin effects, without referring to product categories. More specifically, the respondents have had to express their willingness to buy different products and they had to match countries and products. Many Likert scales has been utilised to understand the consumer behavior and their preferences. The Likert scales have been composed of 7 level, with the level 4 as the absence of influence of COE. All Likert scales aiming to understand the consumers' behaviours in the decision-making process concerning their willing to buy goods in different categories. Two Likert scales have been associated to each product category, one represents the influence of the $\mathrm{COO}$ in a desired purchase and the other one the influence of $\mathrm{COO}$ in an actual purchase. Finally, two different regression models for each country were estimated to understand if the COE in a product category were significantly relevant: one concerning desired purchase and one concerning an actual purchase.

\section{Results:}

\section{Convenience goods category}

The $\mathbf{H 1}$ test has been rejected with a p-value of $\mathrm{p}<0.0001$, in this case, the COO has an influence on the consumers' evaluations. The $\mathbf{H} 2$ test has been rejected with a p-value of $\mathrm{p}<0.010$, in this case, the COO has an influence on the consumers' evaluations. The $\mathbf{H 7}$ test has been rejected with a p-value of $\mathrm{p}<0.0001$, in this case, the COO has an influence on the consumers' evaluations. The $\mathbf{H 8}$ test has been rejected with a $\mathrm{p}$-value of $\mathrm{p}<0.0001$, in this case, the COO has an influence on the consumers' evaluations.

\section{Shopping goods category}

The $\mathbf{H 3}$ test has been rejected with $\mathrm{p}$-value of $\mathrm{p}<0.0001$, in this case, the $\mathrm{COO}$ has an influence on the consumers' evaluations. We failed to reject the $\mathbf{H 4}$ because the p-value greater than 0.05 , in this case, the COO has no influence on the consumers' evaluations. We failed to reject the $\mathbf{H 9}$ because the p-value greater than 0.05 , in this case, the COO has no influence on the consumers' evaluations. We failed to reject the $\mathbf{H 1 0}$ because the p-value is greater than 0.05 , in this case, the $\mathrm{COO}$ has no influence on the consumers' evaluations. We failed to reject many of the hypotheses, especially the hypothesis concerning goods that have been bought from the interviewed before the questionnaire; it means that $\mathrm{COE}$ is not important for this category. 


\section{Specialty goods category}

The $\mathbf{H 5}$ test has been accepted with a p-value greater than 0.05 , in this case, the $\mathrm{COO}$ has no influence on the consumers' evaluations. The $\mathbf{H 6}$ test has been rejected with a p-value $<0.001$, in this case, the $\mathrm{COO}$ has an influence on the consumers' evaluations. The H11 test has been rejected with a pvalue $<0.000$, in this case, the $\mathrm{COO}$ has an influence on the consumers' evaluations. The $\mathbf{H 1 2}$ test has been rejected with a p-value $<0.000$, in this case, the $\mathrm{COO}$ has an influence on the consumers' evaluations. In this category COE have an important influence on consumer behaviour, many hypothesis has been rejected. The COI in this category can be a crucial variable for the decision-making process of customers concerning a future purchase, this characteristic seems to be explicit requested from the consumers and it gives intangible value to a product. A marketing strategy can obtain advantage from the utilization of a specific origin/product match.

\section{Cross-national analysis}

Table 1: Cross-national analysis

\begin{tabular}{|c|c|c|c|}
\hline \multicolumn{4}{|c|}{ Desired purchase } \\
\hline Question & $\begin{array}{c}\text { Italy } \\
\text { Likert scale mean }\end{array}$ & $\begin{array}{c}\text { Great Britain } \\
\text { Likert scale mean }\end{array}$ & Gap \\
\hline $\begin{array}{l}\text { Convenience } \\
\text { goods }\end{array}$ & 5,30 & 3,41 & $+1,89$ \\
\hline Shopping goods & 5,26 & 4,09 & $+1,17$ \\
\hline Specialty goods & 5,44 & 5,72 & $-0,28$ \\
\hline \multicolumn{4}{|c|}{ Actual purchase } \\
\hline Question & $\begin{array}{c}\text { Italy } \\
\text { Likert scale mean }\end{array}$ & $\begin{array}{c}\text { Great Britain } \\
\text { Likert scale mean }\end{array}$ & Gap \\
\hline $\begin{array}{l}\text { Convenience } \\
\text { goods }\end{array}$ & 4,74 & 4,38 & $+0,36$ \\
\hline Shopping goods & 4,41 & 4,13 & $+0,28$ \\
\hline Specialty goods & 4,63 & 4,97 & $-0,34$ \\
\hline
\end{tabular}

Table 1 shows there are gaps concerning the moment of thinking about a future purchase. The "pre purchase" variables about convenience goods and shopping goods have a gap of " 1.89 " and " 1.15 ", that in a scale of 7 represents a big difference. In these variables, Italian people seem to be quite influenced, while the British seem to keep a neutral stance to the COE. The only similar values in this respect concerns "pre-purchase specialty goods", where British people are more influenced than Italian ones with a value of "5.72" against "5.44", and a total gap of " 0.28 ". This result confirms what was said above concerning Britain, namely that the influence of the COE in this category is 
attested. Moreover, the other categories variables - as for purchased goods illustrate similar results: Italian people are more influenced in convenience goods and shopping goods than British people, with a slighter gap than above, respectively " 0.36 " and " 0.28 ". The respondents are more similar in buying a good than when they are thinking about a potential purchase, showing that the $\mathrm{COE}$ is not so different. Finally, there are not important difference in reality concerning $\mathrm{COE}$ in the two countries since the gap is lesser than 0.50 of 1 point Likert scale.

\section{Discussion}

Results concerning convenience, shopping and specialty product categories in Great Britain and Italy are very similar: in both countries the hypotheses concerning the absence of influence in convenience and specialty goods have been rejected, but consumers have different behaviours. Firstly, the consequence of a domestic bias that is the preference of domestic consumers to buy domestic products rather than foreign products, especially in the food market. Secondly, the result of real COE: consumers have been influenced by the origin of product and they have clearly identified different countries. The hypotheses accepted in the shopping goods category are unexpected results: in literature review, previous studies have found significant influence of COE in this category while results of this research are different and show how less influence that can be correlate with the age of the respondents, that brings a question if future generation will be less influenced by COE. The comparison whiting the countries have shown that the behaviours of Italian and British consumers are very similar and especially in the real purchases there is no difference, while when they had to think about future purchases there was a light gap. Although specialty goods category is the most sensible and afflicted category by the COE and only in this category the product's origin can be used as a competitive advantage in a product strategy. In the convenience goods, the origin of a product can be part of a strategy and the existence of a domestic bias is a result that was predictable at the beginning of the research. Teenagers are sensitive to a product of their countries especially in short amount of decision time. The effects of the domestic bias are strong, they can be important in the launching of a national product to give it a sort of additional, perceived value that is intrinsic with the origin. However, goods are part of this category do not need a strong effort during the purchase and the decision-making process is short and consumer's decisions can be instinctive. 


\section{Conclusion and future research:}

This study shows that the gap between two countries in each product category - even if there are populations that are more influenced by the COE - is not as wide as expected. Future research could analyse a huge number of goods in different countries and discuss if the customers' behaviours are similar too.

\section{References:}

1. Andehn, M., Nordin, F., and Nilsson, M.E. (2015). Facets of country image and brand equity: Revisiting the role of product categories in country-of origin effect research. Journal of Consumer Behaviour; 15(3): 225-238.

2. Bassi Suter, M., Mendes Borini, F., Eliete Floriani, D., Da Silva, D. and Polo, E. (2018). Country-of-origin image (COI) as a country specific advantage (CSA): scale development and validation of COI as a resource within the firm perspective. Journal of Business Research; 84: 46-58.

3. Costa, C., Carniero, J., and Goldszmidt, R. (2016). A contingental approach to country-of-origin effects on foreign products evaluation: interaction of facets of country image with product classes. International Business Review; 25(5): 1066-1075.

4. Ferreira, J.J.M., Fernandes, C.I., and Raposo, M.L. (2017). The effects of location on firm innovation capacity. Journal of Knowledge Economy; 8: 77-96.

5. Karimov, F., and El-Murad, J. (2019). Does country-ot-origin matter in the era of globalization? Evidence from cross sectional data in Uzbekistan. International Journal of Retailing and Distribution Management; 47(3): 262-277.

6. Kehagias, J., Skourtis, E., and Vassilikopoulo, A., (2009). Plaiting pricing into product categories and corporate objectives. Journal of Product and Brand Management; 18(1): 67-76.

7. Listiana, E. (2015). Country of origin image and it's impact on brand association, perceived quality and brand loyalty. Journal of Marketing and Consumer Research; 10: 19-30.

8. Momani, R.A. (2015). The impact of brand dimension on the purchasing decision making of the Jordanian consumer for shopping goods. International Journal of Business and Social Science; 6(7): 149168.

9. Rafi, M.A., and Rafi, N. (2015). Impact of specialty goods specifications on customer's purchase intentions. Management and Administrative Sciences Review, 4(3): 555-567. 
10. Rasha, H.A.M. (2015). The impact of country of origin and country of manufacture of a brand on overall brand equity. International Journal of Marketing Studies; 7(2): 70-83.

11. Seeman, R., Gould, S., Chao, M., and Grein, A. (2019). We don't see it at the same way. European Journal of Marketing; 53(5): 989-1104.

12. Sjostrom, T., Corsi, A., and Lockshin, L. (2016). What characteristics luxury products? A study across product categories. International Journal of Wine Business Research; 28(1): 76-95.

13. Yoon, S., and Lee, H. (2019). Empirical validation of the country-ofcultural origin model: does cultural experience affect purchase intention? Journal of International Consumer Marketing; 31(1): 53-65. 